\title{
OCENA BEZPIECZEŃSTWA NA PRZEJŚCIACH DLA PIESZYCH PRZY POMOCY ANALIZY OBRAZU WIDEO
}

\begin{abstract}
Pomimo ogólnej poprawy bezpieczeństwa ruchu drogowego w Polsce, liczba wypadków na przejściach dla pieszych nie zmniejszyła się w ciągu ostatnich czterech lat. W niniejszym artykule przedstawiono rezultaty projektu badawczego MOBIS, którego celem było opracowanie zastępczych miar bezpieczeństwa, opartych na wykrywaniu konfliktów pomiędzy pieszymi i pojazdami z wykorzystaniem analizy obrazu wideo. W okresie ponad 40 dni zarejestrowano ruch pieszych i pojazdów na dwóch przejściach dla pieszych bez sygnalizacji świetlnej w Warszawie i we Wrocławiu. Przy wykorzystaniu przetwarzania obrazu określono trajektorie ruchu pojazdów i pieszych. Uzyskano od 600 do 1000 sytuacji spotkań pieszy-pojazd dziennie. Obliczono parametry opisujące interakcje pieszych i pojazdów - profile prędkości, minimalną odległość między uczestnikami, przyspieszenia itp. Klasyfikacja sytuacji została oparta na interakcjach pieszych i pojazdów.. Na podstawie czasu po opuszczeniu strefy konfliktu (PET) oraz prędkości pojazdu zidentyfikowano sytuacje niebezpieczne. Jako zastępczą miarę bezpieczeństwa na przejściach dla pieszych zaproponowano Wskaźnik Zagrożenia Pieszych (WZP), który określa promil sytuacji niebezpiecznych występujących na danym przejściu.
\end{abstract}

Słowa kluczowe: bezpieczeństwo pieszych, przejścia dla pieszych, metoda konfliktów, analiza obrazu

\footnotetext{
${ }^{1}$ Autor do korespondencji/corresponding author: Piotr Szagała, Politechnika Warszawska, Wydział Inżynierii Lądowej, Al. Armii Ludowej 16, 00-637 Warszawa, tel. +48 22 8253727, p.szagala@il.pw.edu.pl

${ }^{2}$ Witold Czajewski, Politechnika Warszawska, Instytut Sterowania i Elektroniki Przemysłowej, ul. Koszykowa 75, 00-662 Warszawa, tel. +48 22 2345622, w.czajewski@isep.pw.edu.pl

3 Paweł Dąbkowski, Politechnika Warszawska, Wydział Inżynierii Lądowej, Al. Armii Ludowej 16, 00-637 Warszawa, tel. +48 22 2341536, p.dabkowski@il.pw.edu.pl

${ }^{4}$ Piotr Olszewski, Politechnika Warszawska, Wydział Inżynierii Lądowej, Al. Armii Ludowej 16, 00-637 Warszawa, tel. +48 22 8253727, p.olszewski@il.pw.edu.pl
} 


\section{Wprowadzenie}

Piesi są grupą poddaną największemu ryzyku wypadków drogowych. Nie są oni chronieni przez karoserię pojazdu, pasy bezpieczeństwa czy kaski, przez co są szczególnie narażeni na odniesienie poważnych obrażeń oraz mają mniejsze szanse na przeżycie wypadku. W roku 2014 w Unii Europejskiej zginęło około 5556 pieszych, co stanowiło $22 \%$ wszystkich ofiar śmiertelnych.

Poziom bezpieczeństwa pieszych w Polsce należy do najniższych w Unii Europejskiej. W 2015 roku na polskich drogach zginęło 915 pieszych $(31 \%$ wszystkich ofiar śmiertelnych), a 8040 zostało rannych (20\% wszystkich rannych). W dużych miastach piesi stanowią ponad $60 \%$ wszystkich ofiar śmiertelnych. W latach 2008-2013 spośród wszystkich pieszych ofiar wypadków drogowych około $13 \%$ zostało zabitych, a $26 \%$ rannych na przejściach dla pieszych bez sygnalizacji świetlnej, czyli w miejscach gdzie teoretycznie powinni być bezpieczni. Chociaż bezpieczeństwo na polskich drogach generalnie się poprawia, to liczba wypadków na przejściach dla pieszych nie zmalała w przeciągu ostatnich czterech lat, co budzi poważne obawy. Problem związany z dużym zagrożeniem bezpieczeństwa pieszych jest dobrze znany i opisany w polskiej i zagranicznej literaturze ([1], [2], [3]). Poprawa bezpieczeństwa pieszych na przejściach jest jednym z priorytetowych celów Narodowego Programu Bezpieczeństwa Ruchu Drogowego [4].

Referat przedstawia rezultaty projektu badawczego MOBIS, sfinansowanego przez Narodowe Centrum Badań i Rozwoju. Celem projektu było opracowanie zastępczych miar bezpieczeństwa pieszych na podstawie detekcji sytuacji niebezpiecznych przy użyciu analizy obrazu wideo. Miary takie umożliwiają rzetelną ocenę bezpieczeństwa pieszych na przejściach bez sygnalizacji świetlnej.

\section{Poligony badawcze oraz zbieranie danych}

W trakcie projektu ruch pieszych i pojazdów był rejestrowany na dwóch przejściach w Warszawie i dwóch we Wrocławiu przez około dwa miesiące na każdym z nich. Do dalszej analizy wykorzystano około jednego miesiąca nagrań. Wyboru poligonów badawczych dokonano na podstawie liczby wypadków z udziałem pieszych. Dwa przejścia dla pieszych w Warszawie znajdują się na czteropasowym odcinku ulicy (dwa pasy w każdym kierunku oddzielone azylem dla pieszych). Każdy z pasów monitorowany był w kierunku nadjeżdżania pojazdów. Przejścia we Wrocławiu zlokalizowane są na ulicy jednojezdniowej dwupasowej, w rejonie skrzyżowania. Każde z przejść było objęte zasięgiem systemu kamer wideo, jednakże ruch pojazdów rejestrowany był tylko z jednego kierunku. Referat przedstawia wyniki analiz wykonanych dla dwóch poligonów badawczych: Warszawa kierunek ruchu wschód-zachód (nazwany POW) oraz Wrocław kierunek wschód-zachód (nazwany CEN). Szkice obu poligonów przestawione są na rys. 1 . 
a) Warszawa kierunek POW

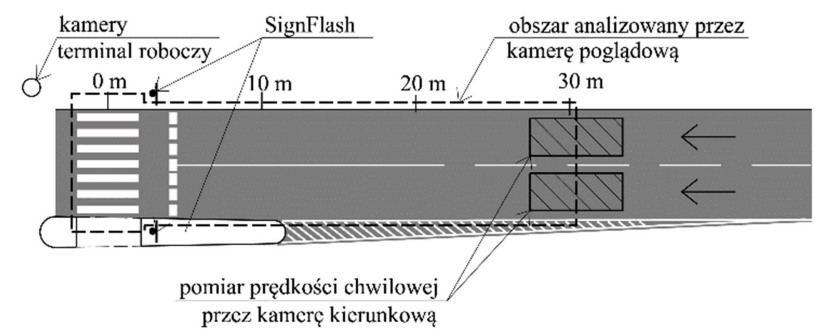

b) Wrocław kierunek CEN

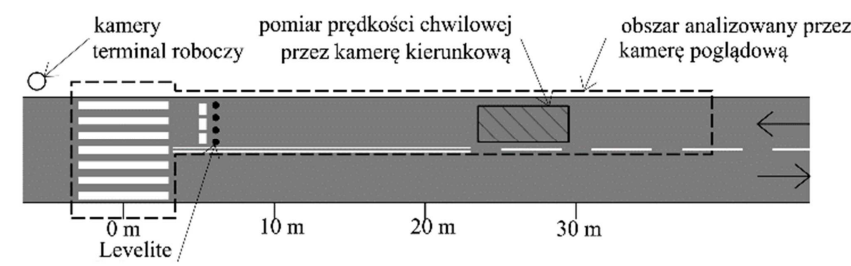

Rys. 1. Szkic poligonów badawczych w Warszawie oraz we Wrocławiu

Fig. 1. Layouts of the survey sites in Warsaw and Wrocław

$\mathrm{Na}$ analizowanych przejściach zainstalowano oraz poddano ocenie urządzenia mające poprawić bezpieczeństwo ruchu. W Warszawie zainstalowano system SignFlash (SF), czyli aktywne oznakowanie wyposażone w czujnik, który po wykryciu pieszego uruchamia pulsujące światła zamontowane nad znakiem D-6 [5]. Ruch na przejściu rejestrowany był przed i po zamontowaniu ww. systemu. Do dalszej, bardziej szczegółowej analizy zostały wybrane 23 dni z korzystnymi warunkami pogodowymi (dni pochmurne, bez wyraźnych cieni, bez opadów itd.) - 12 dni bez systemu SF oraz 11 dni z działającym systemem SF. We Wrocławiu przetestowano system aktywnego oznakowania LeveLite (LL), w którym diody LED o przerywanym świetle zostały wbudowane w nawierzchnię jezdni. Na omawianym w artykule kierunku CEN system LL działał w trybie ciągłym, tzn. niezależnie od obecności pieszych.

Na każdym z poligonów badawczych zainstalowano specjalny system rejestracji oraz przetwarzania obrazu wideo. W jego skład wchodziły następujące elementy:

- cyfrowa kamera poglądowa monitorująca obszar przejścia dla pieszych oraz jezdnię na odcinku 30-40 m przed przejściem,

- jedna cyfrowa kamera kierunkowa na pas, monitorująca odcinek drogi o wymiarach 3,5 x 6 m, znajdujący się w polu widzenia kamery poglądowej,

- stacja robocza do gromadzenia danych oraz wstępnej analizy obrazu z kamer wideo, dodatkowo umożliwiająca diagnostykę systemu.

W tabeli 1 przedstawiono zestawienie zgromadzonych danych. 
Tabela 1. Zestawienie zebranych danych

Table 1. Summary of the data gathered

\begin{tabular}{|c|c|c|c|c|c|}
\hline \multirow{2}{*}{$\begin{array}{c}\text { Poligon } \\
\text { badawczy }\end{array}$} & \multicolumn{2}{|c|}{ Okres badań } & $\begin{array}{c}\text { Liczba monito- } \\
\text { rowanych dni }\end{array}$ & $\begin{array}{c}\text { Liczba anali- } \\
\text { zowanych dni }\end{array}$ & Urządzenie brd \\
\cline { 2 - 6 } & od & do & 49 & 23 & SignFlash (SF) \\
\hline Warszawa POW & 23.09 .2013 & 19.12 .2013 & 18 & LeveLite (LL) \\
\hline Wrocław CEN & 01.08 .2014 & 27.11 .2014 & 103 & 18 & \\
\hline
\end{tabular}

\section{Klasyfikacja interakcji pieszy-pojazd}

Materiał uzyskany z kamer poglądowych posłużył do szczegółowej analizy interakcji zachodzących pomiędzy pieszymi a pojazdami. Interakcje są to sytuacje, w których zarówno pieszy, jak i pojazd znajdują się w kadrze kamer poglądowych. Średnia liczba takich sytuacji na dzień wynosiła w przypadku Warszawy około 600 , a Wrocławia - około 800 . W przeprowadzonych badaniach pominięto analizę grup pieszych, przede wszystkim dlatego, że wykorzystane algorytmy rozpoznawania pieszych nie radziły sobie dobrze z tłumem i generowały niepoprawne trajektorie przeskakujące pomiędzy pieszymi w grupie. Wydaje się jednak, że grupy pieszych, jako większe i lepiej widoczne są mniej narażone na ryzyko kolizji niż pojedynczy piesi.

Klasyfikacja interakcji została przeprowadzona na podstawie opracowanego algorytmu analizującego trajektorie uzyskane z obrazu wideo. Bazował on na wzajemnym położeniu pieszego i pojazdu oraz ich ruchu względem siebie, np.: kierowca przepuścił lub nie przepuścił pieszego w momencie, kiedy zarówno pojazd, jak i pieszy znajdowali się na przejściu; pojazd przejechał przed lub za pieszym. Każda sytuacja została zaklasyfikowana do jednej z następujących kategorii:

- sytuacja A1 - pojazd przejeżdża bezpośrednio przed pieszym znajdującym się na przejściu,

- sytuacja A2 - pojazd przejeżdża przed pieszym stojącym na chodniku,

- sytuacja B - pojazd przejeżdża bezpośrednio za pieszym znajdującym się na przejściu,

- sytuacja C - pojazd zwalnia lub zatrzymuje się przepuszczając pieszego,

- sytuacja D - pojazd przejeżdża za pieszym, gdy ten opuści już przejście dla pieszych (kierowca nie zwalnia w sposób wyraźny).

Całkowita liczba zarejestrowanych sytuacji oraz ich klasyfikacja zostały pokazane w tabeli 2. Sytuacja A1 przedstawia nieprawidłowe zachowanie kierowcy, kiedy to powinien on przepuścić pieszego będącego już na przejściu. Zarówno sytuacja B jak i C przedstawia przepuszczenie pieszego przez kierowcę (pojazd przejeżdża za pieszym) - jednak w sytuacji typu B pieszy może czuć się o wiele bardziej zagrożony. Sytuacja D nie jest sensu stricto przepuszczeniem, gdyż nie wymaga reakcji kierowcy. Tabela 2 pokazuje, że procent przepuszczeń (sytuacje typu $\mathrm{B}+\mathrm{C} \approx 67 \%$ ) jest wyższy w Warszawie. Jednakże we Wrocławiu po zamontowaniu systemu LL odnotowano wzrost liczby przepuszczeń o około 9,6\%. 

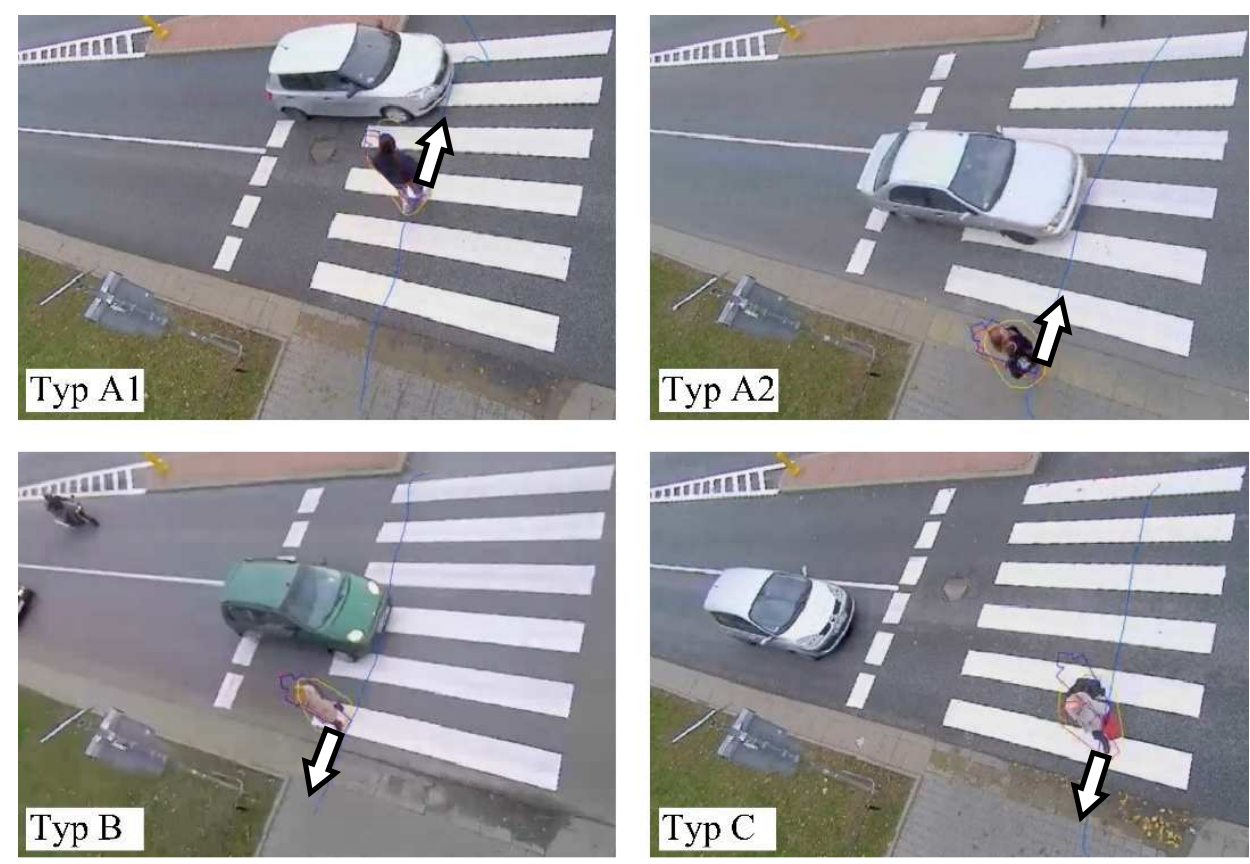

Rys. 2. Schemat typów interakcji pojazd-pieszy (strzałką oznaczono kierunek ruchu pieszego)

Fig. 2. Types of vehicle-pedestrian interactions (the arrows show pedestrian movement direction)

Tabela 2. Liczba oraz rozkład zarejestrowanych interakcji

Table 2. Number and distribution of the recorded interactions

\begin{tabular}{|c|c|c|c|c|c|c|c|c|c|}
\hline $\begin{array}{c}\text { Poligon ba- } \\
\text { dawczy }\end{array}$ & $\begin{array}{c}\text { Urzą- } \\
\text { dzenie brd }\end{array}$ & $\begin{array}{c}\text { Liczba } \\
\text { inter- } \\
\text { akcji }\end{array}$ & $\begin{array}{c}\text { Śr. liczba } \\
\text { interakcji } \\
\text { na dzień }\end{array}$ & A1 & A2 & B & C & D & Suma \\
\hline $\begin{array}{c}\text { Warszawa } \\
\text { POW }\end{array}$ & bez SF & 7103 & 588 & $3,8 \%$ & $16,3 \%$ & $14,9 \%$ & $52,0 \%$ & $13,0 \%$ & $100 \%$ \\
\hline $\begin{array}{c}\text { Warszawa } \\
\text { POW }\end{array}$ & z SF & 6335 & 576 & $4,0 \%$ & $16,1 \%$ & $15,3 \%$ & $52,2 \%$ & $12,3 \%$ & $100 \%$ \\
\hline $\begin{array}{c}\text { Wrocław } \\
\text { CEN }\end{array}$ & bez LL & 11595 & 828 & $11,4 \%$ & $41,5 \%$ & $8,5 \%$ & $30,5 \%$ & $8,0 \%$ & $100 \%$ \\
\hline $\begin{array}{c}\text { Wrocław } \\
\text { CEN }\end{array}$ & z LL & 3136 & 781 & $12,0 \%$ & $32,3 \%$ & $9,5 \%$ & $39,1 \%$ & $7,0 \%$ & $100 \%$ \\
\hline
\end{tabular}

\section{Identyfikacja sytuacji niebezpiecznych}

Metody oceny bezpieczeństwa pieszych oparte na miarach zastępczych polegają na wykrywaniu sytuacji konfliktowych i obliczaniu różnego rodzaju wskaźników, jak np.: Time to Collision (TTC), Deceleration to Safety Time (DST), Post Encroachment Time (PET) itd. [6], [7]. Parametry te, aby mogły być obliczone w sposób automatyczny potrzebują bardzo dokładnych danych 
wejściowych (trajektorii). Jednym z celów projektu MOBIS było przetestowanie nowego wskaźnika bezpieczeństwa (miary zastępczej) dla interakcji pieszypojazd. Wskaźnik ten powinien określać poziom bezpieczeństwa w automatyczny sposób, bazując wyłącznie na analizie obrazu wideo danego przejścia.

$\mathrm{Na}$ podstawie analizy obrazu wideo można uzyskać trajektorie zarówno pieszego, jak i pojazdu. Dzięki temu można stosunkowo łatwo obliczyć w każdym momencie wzajemną pozycję pieszy-pojazd. Szczególnie interesująca jest wartość czasu po opuszczeniu (PET), który określa różnicę czasu między momentem opuszczenia strefy konfliktu przez jednego $\mathrm{z}$ uczestników ruchu a momentem osiągnięcia strefy konfliktu przez drugiego. Wartość ta może być użyta jako wskaźnik bezpieczeństwa danej sytuacji. Sytuacje, dla których obliczona wartość PET jest poniżej 1 sekundy uznaje się za poważny konflikt [8].

Kolejnym przydatnym wskaźnikiem bezpieczeństwa jest prędkość pojazdu $\mathrm{w}$ momencie minimalnej odległości pieszy-pojazd $\left(\mathrm{V}_{\mathrm{Smin}}\right)$. Gdyby doszło do wypadku, prędkość ta byłaby prędkością uderzenia oraz głównym czynnikiem wpływającym na ciężkość wypadku. Według [9], w momencie kiedy pieszy zostanie uderzony z prędkością $27,5 \mathrm{~km} / \mathrm{h}(7,64 \mathrm{~m} / \mathrm{s})$ prawdopodobieństwo śmierci lub ciężkich obrażeń wynosi $10 \%$. Na rys. 3 pokazano sposób wyznaczania prędkości pojazdu w momencie minimalnej odległości pieszy-pojazd $\left(S_{\min }\right)$. Pieszy reprezentowany jest przez okrąg o średnicy równej $0,9 \mathrm{~m}$, natomiast pojazd przez prostokąt o wymiarach $4,5 \mathrm{~m}$ na $1,8 \mathrm{~m}$.

$\operatorname{typ} A$

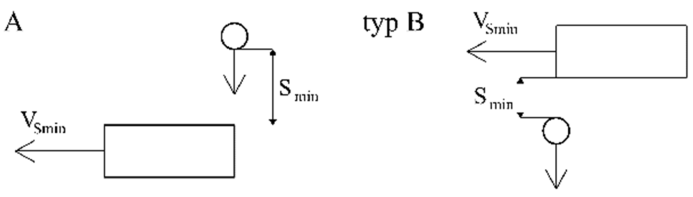

Rys. 3. Schemat sposobu wyznaczania prędkości pojazdu w momencie minimalnej odległości

Fig. 3. Scheme of the vehicle speed calculation method at the moment of minimum distance

Dla sytuacji typu A1 oraz B na poligonie w Warszawie wyznaczono dystrybuantę wartości PET oraz prędkości pojazdu w momencie minimalnej odległości pieszy-pojazd. Sytuacje te przeanalizowano wspólnie ze względu na to, że - w odróżnieniu do pozostałych sytuacji - pieszy i pojazd znajdują się w niewielkiej odległości od siebie, w związku z czym można zastosować te same wskaźniki. Jakościowo są to jednak zupełnie inne sytuacje i uzyskane wyniki trzeba rozpatrywać rozłącznie. Na rys. 4a można zauważyć, że bez systemu SF dla $24 \%$ wszystkich sytuacji typu A1 czas po opuszczeniu wynosił mniej niż $1 \mathrm{~s}$, a dodatkowo około $10 \%$ kierowców przejeżdżało za pieszymi (sytuacja typu B) w odstępie czasu krótszym niż $1 \mathrm{~s}$. Jednakże nie wszystkie te sytuacje były niebezpieczne, gdyż w wielu przypadkach prędkość pojazdu była niewielka. $\mathrm{Na}$ rys. 4b widać, że $50 \%$ kierowców w sytuacjach typu A1 przejeżdża z prędkością większą niż 42,5 km/h (bez zainstalowanego systemu SF), natomiast przy dzia- 

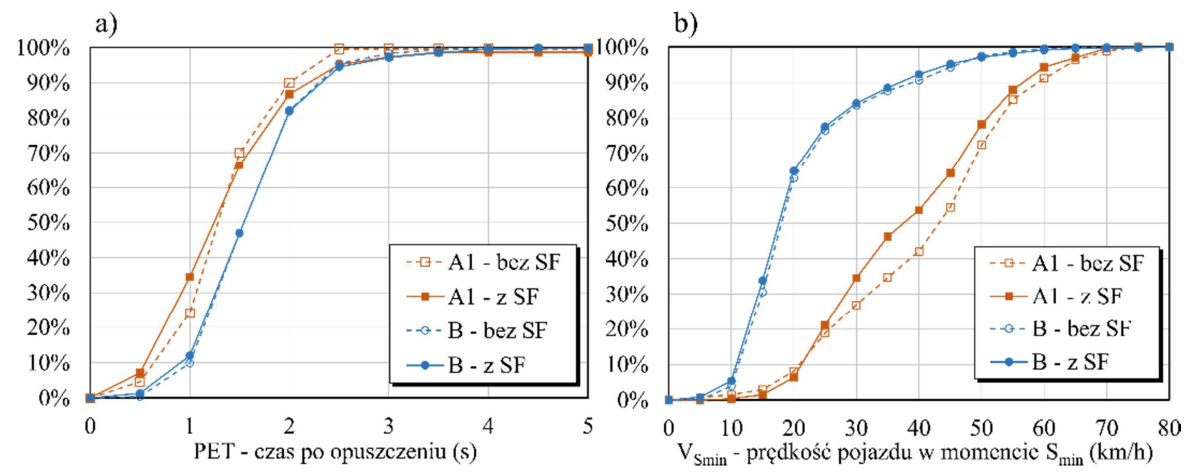

Rys. 4. Warszawa - dystrybuanta: a) czasu po opuszczeniu, b) prędkości pojazdów w momencie minimalnej odległości

Fig. 4. Warsaw - cumulative distribution of: a) PET, b) vehicle speeds at the moment of minimum distance

łającym systemie $S F$ z prędkością większą niż $37,5 \mathrm{~km} / \mathrm{h}$. Różnica $5,5 \mathrm{~km} / \mathrm{h}$ pokazuje pozytywny wpływ systemu SF, jednak kierowcy decydowali się na przejazdy bliżej pieszych, o czym świadczy pogorszenie się wartości PET.

Podobną analizę rozkładu PET oraz $\mathrm{V}_{\text {Smin }}$ przeprowadzono w odniesieniu do poligonu badawczego we Wrocławiu. Wyniki przedstawione na rys. 5a pokazują, że bez systemu SF dla 23\% wszystkich sytuacji typu A1 czas po opuszczeniu wynosił mniej niż $1 \mathrm{~s}$, a dodatkowo około $12 \%$ kierowców przejeżdżało za pieszymi (sytuacja typu B) w czasie krótszym niż $1 \mathrm{~s}$. Na rys. 5b można natomiast zobaczyć, że 50\% kierowców przejeżdża przed pieszym (sytuacja A1) z prędkością większą niż $41,5 \mathrm{~km} / \mathrm{h}$ bez systemu LeveLite oraz $\mathrm{z}$ prędkością większą niż $32,5 \mathrm{~km} / \mathrm{h}$ z LL. Różnica $9 \mathrm{~km} / \mathrm{h}$ świadczy o pozytywnym wpływie zainstalowanego systemu na bezpieczeństwo pieszych. Przy zamontowanym systemie LL w sy-
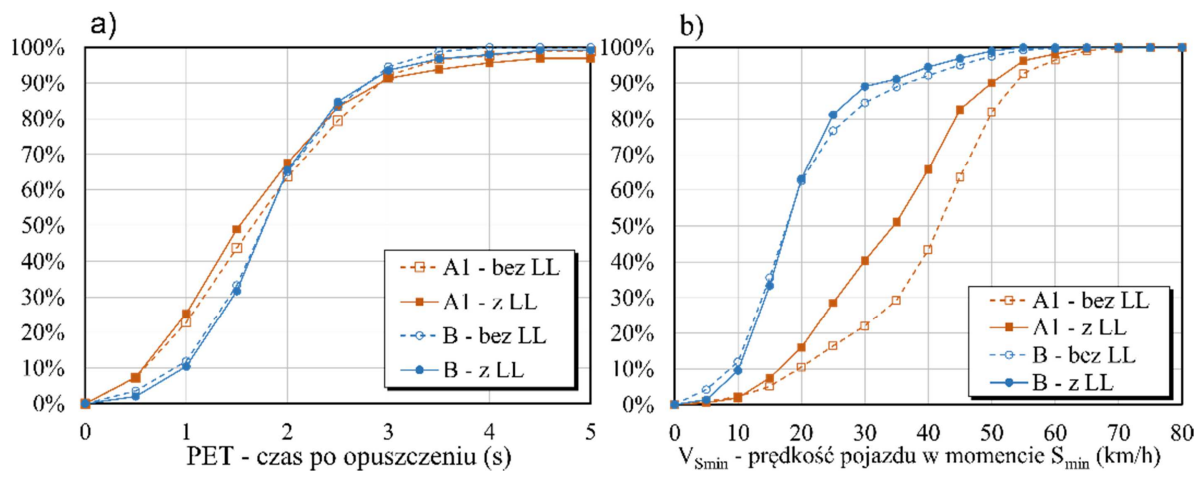

Rys. 5. Wrocław - dystrybuanta: a) czasu po opuszczeniu, b) prędkości pojazdów w momencie minimalnej odległości

Fig. 5. Wrocław - cumulative distribution of: a) PET, b) vehicle speeds at the moment of minimum distance 
tuacjach typu A1 kierowcy decydowali się na przejazdy bliżej pieszych, o czym świadczy przesunięcie dystrybuanty PET.

Identyfikacja niebezpiecznych sytuacji typu $\mathrm{C}$ wymaga innego podejścia. Analiza wartości prędkości pojazdu w momencie minimalnej odległości pieszy-pojazd nie jest w tym przypadku przydatna, ponieważ w wielu sytuacjach typu $C$ prędkość $\mathrm{V}_{\text {Smin }}$ jest równa zero - pojazd zatrzymuje się przed pieszym. Wartość opóźnienia nie jest też wystarczająco dobrym wskaźnikiem w sytuacji, gdy pojazd hamował w dużej odległości od przejścia. Także wartość PET jest w takich przypadkach relatywnie duża, ponieważ pojazd, aby minąć pieszego po wyhamowaniu, jest zmuszony do ruszania z zatrzymania. Groźne sytuacje typu C mają miejsce wtedy, gdy kierowca zbliża się do przejścia z dużą prędkością i gwałtownie hamuje tuż przed pieszym. Aby zidentyfikować takie przypadki, przeanalizowano dystrybuanty prędkości pojazdów w odległości 5 i $10 \mathrm{~m}$ od krawędzi przejścia dla pieszych (rys. 6). W ocenie sytuacji typu C istotna jest prędkość krytyczna, przy której pojazd jest w stanie wyhamować przed przejściem dla pieszych. Przyjęto, że dana sytuacja była groźna, gdy pojazd miał opóźnienie co najmniej $4 \mathrm{~m} / \mathrm{s}^{2}$ [10]. Odpowiednio przekształcając wzór ogólny na przyspieszenie pojazdu w ruchu jednostajnie opóźnionym uzyskamy:

$$
\mathrm{V}_{\text {crit }}=\sqrt{2 \cdot \mathrm{s} \cdot \mathrm{d}=} \sqrt{2 \cdot 10 \cdot 4}=8,94 \mathrm{~m} /
$$

gdzie: $\mathrm{s}$ - droga hamowania $(10 \mathrm{~m})$,

d - maksymalne bezpieczne opóźnienie $\left(4 \mathrm{~m} / \mathrm{s}^{2}\right)$.

Dlatego też sytuacje typu C, w których prędkość pojazdu w odległości $10 \mathrm{~m}$ od przejścia przekracza $8,94 \mathrm{~m} / \mathrm{s}(32,2 \mathrm{~km} / \mathrm{h})$ są traktowane jako potencjalnie niebezpieczne. Kierowca w tych przypadkach musiał hamować gwałtownie, aby nie znaleźć się na przejściu jednocześnie z pieszymi. Na podstawie rys. 6 można

a) Warszawa kierunek POW

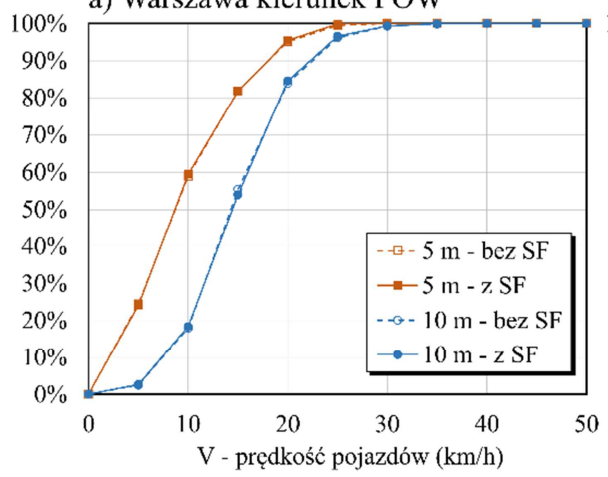

b) Wrocław kierunek CEN

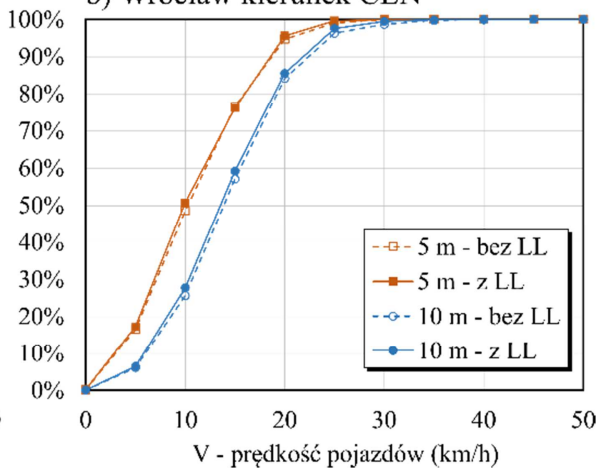

Rys. 6. Dystrybuanta prędkości pojazdów 5 oraz 10 metrów przed przejściem dla pieszych - dla sytuacji typu $\mathrm{C}$

Fig. 6. Cumulative distribution of vehicle speeds 5 and 10 meters before the pedestrian crossing situation type $\mathrm{C}$ 
zauważyć, że takich przypadków zarówno w Warszawie, jak i we Wrocławiu jest około $0,5 \%$. Analiza trajektorii pieszych wykazała, że na badanych poligonach większość pieszych porusza się środkiem przejścia dla pieszych.

Autorzy referatu proponują identyfikację niebezpiecznych sytuacji typu A1 i B na podstawie wartości PET oraz prędkości pojazdu w momencie minimalnej odległości. W przypadku sytuacji typu $\mathrm{C}$ istotną wartością jest prędkość pojazdów w odległości 10 metrów od krawędzi przejścia dla pieszych. Podsumowując, przy identyfikacji zdarzeń niebezpiecznych przyjęto następujące kryteria:

- dla sytuacji typu A1 i B - gdy PET $\leq 1 \mathrm{~s}$ oraz $\mathrm{V}_{\text {Smin }} \geq 7,64 \mathrm{~m} / \mathrm{s}$,

- dla sytuacji typu C - gdy prędkość pojazdu 10 metrów od przejścia $\mathrm{V}_{\mathrm{s}}>\mathrm{V}_{\text {crit }}=8,94 \mathrm{~m} / \mathrm{s}$.

Wskaźnik Zagrożenia Pieszych (WZP) jest zdefiniowany jako udział sytuacji niebezpiecznych w ciągu całego dnia, wyrażony w promilach:

$$
W Z P=\frac{N D_{A B}+N D_{C}}{N_{A B C}} \cdot 10000
$$

gdzie: $\mathrm{ND}_{\mathrm{AB}}-$ liczba sytuacji niebezpiecznych typu $\mathrm{A} 1$ i B na dzień,

$\mathrm{ND}_{\mathrm{C}}$ - liczba sytuacji niebezpiecznych typu $\mathrm{C}$ na dzień,

$\mathrm{N}_{\mathrm{ABC}}$ - liczba zarejestrowanych interakcji pojazd-pieszy na dzień (sytuacje typu A1, A2, B i C).

Jak można zobaczyć w tabeli 3, średnia liczba sytuacji niebezpiecznych na dzień na poligonie we Wrocławiu jest większa niż w Warszawie. Wpływ na to może mieć większe natężenie ruchu zarówno pojazdów jak i pieszych, a co za tym idzie większa liczba interakcji pieszy-pojazd na dzień. Jednocześnie na trudniejszą sytuację pieszych we Wrocławiu niewątpliwy wpływ ma brak azylu. $\mathrm{Na}$ obu poligonach badawczych średnia liczba sytuacji niebezpiecznych na dzień zmalała po zainstalowaniu aktywnego oznakowania mającego poprawić bezpieczeństwo ruchu.

Tabela 3. Analiza sytuacji niebezpiecznych

Table 3. Analysis of the hazardous situations

\begin{tabular}{|c|c|c|c|c|c|c|c|c|}
\hline \multirow{2}{*}{$\begin{array}{c}\text { Poligon } \\
\text { badawczy }\end{array}$} & \multirow{2}{*}{$\begin{array}{l}\text { Urządze- } \\
\text { nie brd }\end{array}$} & \multirow[t]{2}{*}{ Dni } & \multirow{2}{*}{$\begin{array}{l}\text { Interakcji } \\
\text { na dzień } \\
\mathrm{N}_{\mathrm{ABC}}\end{array}$} & \multicolumn{3}{|c|}{$\begin{array}{l}\text { Sytuacje niebezpieczne, } \\
\text { średnio na dzień }\end{array}$} & \multirow[t]{2}{*}{ WZP } & \multirow[t]{2}{*}{ Zmiana } \\
\hline & & & & $\mathrm{ND}_{\mathrm{AB}}$ & $\mathrm{ND}_{\mathrm{C}}$ & Suma & & \\
\hline \multirow{2}{*}{$\begin{array}{l}\text { War- } \\
\text { szawa }\end{array}$} & Brak & 12 & 512 & 4,1 & 1,0 & 5,1 & $9,9 \%$ & \multirow{2}{*}{$1,3 \%$} \\
\hline & SF & 11 & 501 & 4,4 & 0,5 & 4,9 & $9,8 \% 0$ & \\
\hline \multirow{2}{*}{ Wrocław } & Brak & 3 & 781 & 11,7 & 1,7 & 13,3 & $17,1 \% 0$ & \multirow{2}{*}{$16,5 \%$} \\
\hline & LL & 3 & 888 & 11,0 & 1,7 & 12,7 & $14,3 \% 0$ & \\
\hline
\end{tabular}




\section{Podsumowanie}

Przeprowadzone badania wykazały, że systemy aktywnego oznakowania mają pozytywny wpływ na prędkość pojazdów (spadek nawet o 20\%), ale negatywny wpływ na wartość czasu po opuszczeniu (PET). Przy włączonych migających światłach kierowcy mijali pieszych wolniej, ale w mniejszej odległości.

Proponuje się, aby identyfikować niebezpieczne spotkania dla sytuacji typu A1 i B (przejazd tuż przed lub tuż za pieszym) na podstawie kombinacji wartości czasu po opuszczeniu strefy konfliktu (PET) mniejszej niż 1 sekunda oraz prędkości pojazdu przy minimalnej odległości pieszy-pojazd przekraczającej $7,64 \mathrm{~m} / \mathrm{s}$. W przypadku sytuacji typu C (pojazdy zatrzymują się lub zwalniają by ustąpić pierwszeństwa pieszym), proponowanym wskaźnikiem jest prędkość pojazdu w odległości $10 \mathrm{~m}$ od przejścia przekraczająca krytyczną wartość $32,2 \mathrm{~km} / \mathrm{h}$. Do oceny bezpieczeństwa ruchu proponuje się przyjęcie Wskaźnika Zagrożenia Pieszych (WZP), definiowanego jako promil całkowitej dziennej liczby sytuacji spotkania pieszych i pojazdów, które zostały sklasyfikowane jako niebezpieczne. Porównując oba poligony, można zauważyć, że wartość wskaźnika WZP jest wyższa we Wrocławiu, co wskazuje na niższy poziom bezpieczeństwa. Jest to najprawdopodobniej odzwierciedleniem braku azylu oraz większego natężenia ruchu zarówno pieszych jak i pojazdów, co powoduje, że uczestnicy ruchu decydują się na bardziej ryzykowne zachowania. Na obu poligonach średnia liczba niebezpiecznych sytuacji spadła po instalacji aktywnych systemów oznakowania jako środków poprawy bezpieczeństwa ruchu.

\section{Literatura}

[1] Jamroz K., Wachnicka J.: Ochrona pieszych i rowerzystów na drogach krajowych. Drogownictwo, $\mathrm{nr}$ 4-5, 2009.

[2] Olszewski P., Zielińska A.: Badania i modelowanie bezpieczeństwa pieszych w ruchu drogowym. Transport Miejski i Regionalny, 2012, str. 23-27.

[3] Olszewski P., Szagała P., Wolański M., Zielińska A.: Pedestrian fatality risk in accidents at unsignalized zebra crosswalks in Poland. Accident Analysis \& Prevention, 84, 2015. str. 83-91.

[4] Narodowy Program Bezpieczeństwa Ruchu Drogowego 2013-2020, Krajowa Rada Bezpieczeństwa Ruchu Drogowego, Warszawa, 2013.

[5] Czajewski W., Mrówka P., Olszewski P.: Video Processing for Detection and Tracking of Pedestrians and Vehicles at Zebra Crossings, w: J. Mikulski (ed), Tools of Transport Telematics, Springer, 2015.

[6] Kieć M.: Zastosowanie techniki konfliktów ruchowych jako miary pośredniej w ocenie bezpieczeństwa ruchu drogowego. Logistyka 6/2014, str. 5395-5404.

[7] Davis G., Saunier N., Sayed T., Tarko A., Washington S.: White Paper, Surrogate Measures of Safety, https://wiki.umn.edu/pub/TRB_ANB203/WebHome/ Surrogate_Measures_of_Safety_A_White_Paper_2009.pdf. 
[8] Almodfer, R., et al.: Quantitative analysis of lane-based pedestrian-vehicle conflict at a non-signalized marked crosswalk. Transportation Research Part F (2015).

[9] Tefft B.C.: Impact speed and a pedestrian's risk of severe injury or death. Accident Analysis and Prevention, 50, 2013, str. 871-878.

[10] Hupfer C.: Computergestützte Videobildverarbeitung zur Verkehrssicherheitsarbeit - am Beispiel von Fußgängerquerungen an städtischen Hauptverkehrsstraßen, Universität Kaiserslautern, 1998.

\section{ASSESSMENT OF PEDESTRIAN CROSSING SAFETY USING VIDEO ANALYSIS}

\section{S u m m a r y}

Although road safety situation in Poland is generally improving, the number of accidents at pedestrian crossings has not decreased in the last four years. The paper presents results of research project MOBIS, the aim of which was to develop surrogate safety indicators, based on detection of pedestrian-vehicle conflicts using video analysis. Pedestrian and vehicle traffic was filmed at two unsignalised pedestrian zebra crossings in Warsaw and Wrocław for over 40 days. Motion trajectories of vehicles and pedestrians were determined based on video processing. The number of pedestrian-vehicle encounters was between 600 and 1000 per day. Several parameters describing pedestrian-vehicle interactions were calculated, such as: speed profiles, post encroachment time, minimum distance between the participants, decelerations, etc. Classification of encounters was based on interactions of pedestrians and vehicles i.e.: driver yielding to a pedestrian, vehicle passing just in front of or behind a pedestrian. Dangerous encounters were identified based on PostEncroachment Time (PET) as well as the vehicle speed. Dangerous Encounter Index is proposed as a surrogate safety indicator for pedestrian crossings. The index shows improvement of safety after introduction of active signage involving blinking lights at the crossings.

Keywords: pedestrian safety; pedestrian crossings; road user behaviour; surrogate safety indicator

Przestano do redakcji: 07.06.2016 $r$.

Przyjęto do druku: 30.06.2016 r.

DOI: $10.7862 / \mathrm{rb} .2016 .92$ 
